\title{
The Oxidation of Cellulose from Oil Palm Empty Fruit Bunch by using Hydrogen Peroxide in Alkaline Condition
}

\author{
Isroi $^{1}$, Adi Cifriadi ${ }^{2}$ \\ ${ }^{1}$ Indonesian Research Institute for Biotechnology and Bioindustry, No.1, Taman Kencana Road, Bogor, Indonesia \\ ${ }^{2}$ Indonesian Rubber Research Institute, No.1, Salak Road, Bogor, Indonesia
}

Received : 25 April 2018, Revised: 17 September 2018, Accepted : 28 December 2018

\section{Oksidasi Selulosa dari Tandan Kosong Kelapa Sawit menggunakan Hidrogen Peroksida dalam Kondisi Basa}

\begin{abstract}
Abstrak
Perhatian untuk memanfaatkan selulosa sebagai polimer terbarukan untuk menggantikan polimer tidak terbarukan mengalami peningkatan. Perubahan dan modifikasi kimia selulosa melalui proses oksidasi diperlukan untuk meningkatkan sifat dan fungsi selulosa. Penelitian ini bertujuan untuk mempelajari pengaruh oksidasi selulosa dari tandan kosong kelapa sawit (TKKS) menggunakan hidrogen peroksida dalam suasana basa. Selulosa diisolasi dan dimurnikan dengan metode natrium hidroksida dan dilanjutkan dengan pemutihan natrium hipoklorit. Efek oksidasi selulosa oleh hidrogen peroksida dievaluasi menggunakan analisis komponen lignoselulosa, analisis visual, sifat fisik dan kimia. Analisis spektroskopi inframerah (FTIR) digunakan untuk mengevaluasi perubahan gugus fungsional selulosa. Pemasakan TKKS dengan natrium hidroksida pada suhu $160^{\circ} \mathrm{C}$ selama 4 jam mengurangi kandungan lignin dari $22,58 \%$ menjadi $16,60 \%$, meningkatkan kandungan selulosa dari $60,76 \%$ menjadi $73,87 \%$ dan hemiselulosa dari $25,86 \%$ menjadi $30,95 \%$. Perlakuan pulp TKKS menggunakan natrium hipoklorit menghilangkan semua sisa lignin. Kandungan selulosa meningkat hingga 90,86\%. Oksidasi selulosa dengan hidrogen peroksida menurunkan derajat polimerisasi selulosa dari 1997 menjadi 658. Gugus karboksil selulosa meningkat secara signifikan dan dikonfirmasi dengan analisis titrasi. Analisis visual menunjukkan kerusakan serabut selulosa, sesuai dengan pengurangan kristalinitas selulosa.
\end{abstract}

Kata kunci: selulosa, oksidasi, tandan kosong kelapa sawit, gugus karboksil, kristalinitas, sifat fisik

\begin{abstract}
There are growing interest to use cellulose as renewable material in order to replace non-renewable polymeric materials. Alteration and chemical modifications of the cellulose by oxidation is needed to improve its properties and functionality. The aim of this study was to evaluate oxidation effect of the cellulose from oil palm empty fruit bunch (OPEFB) using hydrogen peroxide in alkaline condition. Cellulose has been isolated and purified by sodium hydroxide method followed by sodium hypochlorite bleaching. The oxidation effect of the cellulose by hydrogen peroxide was investigated by component analysis of the lignocelluloses, visual analysis, physical and chemical properties. Fourier transform infrared spectroscopy was employed to evaluate the changes of functional groups. Digesting of the OPEFB by sodium hydroxide at temperature $160^{\circ} \mathrm{C}$ for 4 hours reduced lignin content from $22.58 \%$ to $16.60 \%$, increase cellulose and hemicelluloses content from $60.76 \%$ to $73.87 \%$ and $25.86 \%$ to $30.95 \%$, respectively. Treatment of the OPEFB pulp using sodium hypochlorite removed all residual lignin. Cellulose content was increased up to $90.86 \%$. Degree of polymerization of the oxidized cellulose was reduced from 1997 to 658. Carboxyl groups of celluloses was significantly increased and confirmed by titration analysis. OPEFB cellulose fiber was damage and broken, meanwhile crystallinity of the cellulose was reduced.
\end{abstract}

Keywords: cellulose, oxidation, oil palm empty fruit bunch, carboxyl group, crystallinity, physical properties 


\section{Introduction}

There are growing interest to replace nonrenewable polymeric materials obtained from petrochemical resource by renewable polymers such as cellulose. Cellulose has been used for long time as fiber source in paper industry. Recently, cellulose also uses for many application, i.e.: biofuel (Piarpuzán et al., 2011), bioplastic (Shen etal., 2010), and composite (Varshney \& Naithani, 2011). Biomass waste from agro-industry is a good source for high cellulose content, such as oil palm empty fruit bunch (OPEFB). Indonesia is the largest oil palm producers in the world, where its production is predicted as about 31 million metric tons of oil palm in 2015 (Dirjenbun, 2015). Crude oil palm (CPO) is extracted from the fruits and the lignocelluloses residual remains as OPEFB. Accumulation of OPEFB in the mill reaches about 28.65 million metric tons per year. OPEFB has low commercial value and constitutes a disposal problem due to its large quantity. Therefore, it is of importance to optimally utilize OPEFB in order to solve these problems and at the same time transform the resources for valuable products.

OPEFB is composed of $40.37 \%$ cellulose, $20.06 \%$ hemicelluloses, and $23.89 \%$ lignin (Isroi, 2015). Having high cellulose content, OPEFB has high potential to be used as a source for cellulose and cellulosic derived products. Various researches and developments have been conducted to produce cellulose and cellulosic derived product from OPEFB, such as cellulose fiber (Khalid et al., 2008), nano-cellulose (Lani et al., 2014; Zianor Azrina et al., 2017; Mohd et al., 2017), glucose (Hamzah et al., 2011), xylose (Zhang et al., 2012), ethanol (Isroi et al., 2014; Sklavounos et al., 2013), and citric acid (Bari et al., 2010). However, the production of cellulose and cellulose derivate is often cumbersome process because cellulose is naturally immersed with other matrix (lignin and hemicelluloses) and it has low reactivity due to large amount of hydrogen bonds which restrict its solubility in all common solvents (Swatloski et al., 2002).

Alteration and chemical modifications of the cellulose are applied during processing and producing of cellulose material. Cellulose modification through oxidation leads to added value products in order to determine macroscopic properties and chemical behavior of cellulosic materials. Cellulose is oxidized when the functional group of carboxylic acids is replaced by one or more of the hydroxyl groups positioned at $\mathrm{C} 2, \mathrm{C} 3$ or $\mathrm{C} 6$. The oxidized cellulose containing carboxyl groups grows special interest due to its usefulness in broad applications, such as: medical, agricultural, cosmetic, and pharmaceutical application (Coseri et al., 2013). Carbonyl and carboxyl groups in oxidized cellulose play a decisive role in the pulping process and therefore in the final paper properties (Kitaoka et al., 1999). Oxidized cellulose fibers have been shown to perform higher sheet density and improved strength-related properties but only if the total carboxyl group content is less than $500 \mathrm{mmol} / \mathrm{kg}$ (Ma et al., 2010). Cellulose can be oxidized by various oxidizing reagents that can be divided into non-selective (such as: permanganates, peroxides and ozone) and selective (such as: periodates and nitroxyl radicals) (Coseri et al., 2013). Hydrogen peroxides has been used in industrial application for pulp bleaching (Brooks \& Moore, 2000). However, it could equally be used to alter the properties of the cellulose. The aims of this study was to evaluate oxidation effect to cellulose that purified from OPEFB using hydrogen peroxide in alkaline condition.

\section{Materials and Methods}

\section{Oil Palm Empty Fruit Bunch}

OPEFB was collected from an oil palm mill in Simalungun, North Sumatera, Indonesia. OPEFB used in this study was fresh OPEFB from the mill, chopped directly, and dried in the same day, until the moisture content was less than $10 \%$. Reducing the water content of OPEFB would reduce the decomposition of OPEFB by native microorganism. Chopping and drying processes were also used to remove kernel and other contaminants. Dried EFB was chopped into approximately $5 \mathrm{~cm}$ long small pieces and stored in a container at room temperature prior to the experiment. It was analyzed for its lignin, cellulose, and hemicelluloses contents.

\section{Cellulose Preparation}

Dried OPEFB was delignified by sodium hydroxide using laboratory rotary digester in the dosage of $10 \mathrm{~g} \mathrm{NaOH} / 100 \mathrm{~g}$ OPEFB with consistency of $10 \%$. Two thousands grams (o.d. basis) of dried OPEFB was put into the 
digester and heated to reach pressure at 2 bars and maintained for 4 hours. Pulp was then washed with water to remove $\mathrm{NaOH}$ residue and black liquor. The pulp was beaten in laboratory beater to get pulp with freeness level of $300 \mathrm{~mL}$ CSF. Sodium hypochlorite $(5.25 \%$ in water) was used for cellulose purification. A hundred grams of pulp (o.d. basis) was treated in a flask containing $3000 \mathrm{~mL}$ of distilled water with $33.5 \mathrm{~g}$ sodium hypochlorite at the temperature of $70-75^{\circ} \mathrm{C}$. The addition of sodium hypochlorite was continued at 2 hours intervals until the cellulose become white. The cellulose was left in acidified condition for 12 hours before washing. Cellulose was washed at least three times to remove all residual sodium hypochlorite.

\section{Oxidation of the Cellulose}

Five g OPEFB cellulose (o.d. basis) was added into $1000 \mathrm{~mL}$ Erlenmeyer flask. The cellulose was then impregnated by $500 \mathrm{~mL}$ of hydrogen peroxide solution with various concentrations $(0 \%, 3 \%, 6 \%$, and $9 \%$ ). The $\mathrm{pH}$ of the solution was maintained at 11 using $0.1 \mathrm{M} \mathrm{NaOH}$ or $0.1 \mathrm{M} \mathrm{HCl}$ solution. The cellulose suspension was continuously shaken with electric shaker for 24 hours. In the end of the reaction, pulp was filtered and washed for at least four times. It was then dried prior to subsequent treatment and analysis.

\section{Analytical Methods}

The cellulose, hemicelluloses, and lignin of the OPEFB were determined according to the ChessonDatta Method (Chesson 1981) and TAPPIStandard. A fourier transform infrared (FTIR) spectrometer (Impact 410 iS10, Nicolet Instrument Corp.) was used for determining changes in the structure of the OPEFB, pulp, and cellulose to the method described in reference (Isroi et al., 2014). Each spectrum was obtained with an average of 32 scans and resolution of $4 \mathrm{~cm}^{-1}$ from $600-4,000 \mathrm{~cm}^{-1}$. The spectrum data was controlled by Nicolet OMNIC 4.1 (Nicolet Instrument Corp.) software and analyzed by eFTIR ${ }^{\circledR}$ (EssentialFTIR, Operant LLC). Fiber and cellulose micro morphology was visualized using light microscope with $400 \mathrm{x}-$ 1000x magnification. Crystallinity of the cellulose presented as lateral order index (LOI) according to methods described in the references (Åkerholm et al., 2004; Abdul, J. M. Jahim, et al., 2016). Degree of polymerization of cellulose was measured by viscometric technique (Hubbell \& Ragauskas, 2010).

The carboxyl content of all cellulose samples was determined by a titration technique described elsewhere (Fras \& Stana-Kleinschek, 2002). An air-dry cellulose sample equivalent to $0.5-1.0 \mathrm{~g}$ was weighted into a $200 \mathrm{~mL}$ glass- stopper flask. A hundred mililiters of calcium acetate solution were added. The flasks were shaken overnight, and the suspension of fibers was then filtrated. The color indicator murexide was used as a metal chromic indicator. The $\mathrm{pH}$ value of the filtrate was adjusted up to 12 by the addition of $0.1 \mathrm{M}$ sodium hydroxide solution. The decrease in concentration of calcium acetate solution after contact with the fibers was determined by titration technique. Solution of 0.1 M EDTA was used as titrant.

\section{Results and Discussion}

\section{Lignocelluloses Content}

Initial lignocelluloses component of dried OPEFB is shown in Table 1. OPEFB used in this study has high cellulose content and low lignin content compared to other references (Isroi, 2015; Law et al., 2007; Rahman et al., 2007; Pujiasih et al., 2018). Range of the lignocelluloses components of OPEFB were $42.7-65 \%$ cellulose, $17.1-33.5 \%$ hemicelluloses, and 13.2-25.31\% lignin (Shinoj et al., 2011). Variation lignocelluloses content of OPEFB could be caused by different raw material source, plant varieties, historic treatment of the OPEFB prior laboratory analysis, and analytical method. OPEFB has highest composition of cellulose compared to other source, such as coir (Haque et al., 2009), rice straw (de Assis Castro et al., 2017), baggase (Chadijah et al., 2018), and kenaf fiber (Alavudeen et al., 2015). Having high cellulose content made OPEFB is a potential resource for cellulose and cellulose derivative product.

Table 1. Initial Lignocelluloses Content of Oil Palm Empty Fruit Bunch

\begin{tabular}{ll}
\hline Component & $(\%)$ \\
\hline Cellulose & 60.76 \\
Hemicelluloses & 25.86 \\
Lignin & 22.58 \\
\hline
\end{tabular}


Changes of the lignocelluloses content of the OPEFB, pulp and bleached pulp is shown in Figure 1. Initial content of the OPEFB was $60.76 \%$ cellulose, $25.86 \%$ hemicelluloses, and $22.58 \%$ lignin. Pulping process of the OPEFB reduce the lignocellulosic content become $73.87 \%$ cellulose, $30.95 \%$ hemicelluloses, and $16.6 \%$ lignin. Lignin content reduced significantly by pulping process and the other components were increased. Lignin is soluble in alkaline solution (i.e. sodium hydroxide), high temperature, and high pressure. On the other hand, cellulose and hemicelluloses are more stable in alkaline solution. Sodium hydroxide was also reported as better chemical to solubilize oil palm fiber than other chemical (Sreekala et al. 1997). Alkaline pulping is currently the most widely used method to reduce lignin content in pulp and paper production (Suhas et al., 2007).

Bleaching of OPEFB pulp by sodium hypochlorite changed the lignocellulosic content. Cellulose was increased from $73.87 \%$ to $90.86 \%$. Hemicelluloses and lignin were reduced from $30.95 \%$ to $27.12 \%$ and $16.6 \%$ to $0 \%$, respectively. Increasing of the cellulose was caused by reducing of the other component. Sodium hypochlorite is strong oxidizing agent and commercially used for pulp and textile bleaching (Taylor et al., 1940). In this study, lignin content was totally removed and hemicelluloses were slightly reduced after sodium hypochlorite treatment. In lignocelluloses model, cellulose is covered by hemicelluloses in lignin (Mosier et al., 2005). Sodium hypochlorite probably attacked the lignin and hemicelluloses prior to cellulose.

Degree of polymerization (DP) of the cellulose was also changed after pulping and bleaching

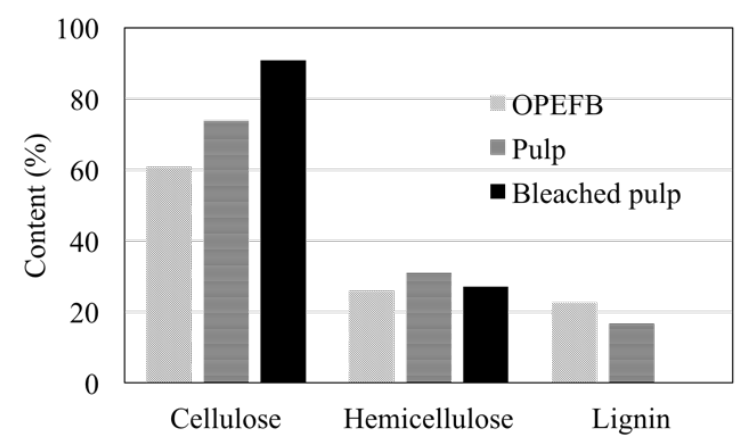

Figure 1. Lignocellulose Component (Cellulose, Hemicellulose and Lignin) of the OPEFB, Pulp, and Bleached Pulp process as shown in Figure 2. Pulping process was slightly reduced DP from 2358 (OPEFB) to 1997 (OPEFB pulp). The DP was significantly reduced after the OPEFB pulp treated by sodium hypochlorite to 658. Sodium hypochlorite seems to cut the cellulose polymer into shorter polymer. The DP of the OPEFB pulp was slightly higher than cellulose fiber from OPEFB reported in the reference (Fahma et al., 2010). Cellulose has two regions that are crystalline and amorphous region. Amorphous region is easier to break and hydrolyzed by chemical or physical processes than the crystalline region.

Pulping and bleaching process of the OPEFB was also reduced length of the OPEFB cellulose fiber. Fiber length distribution of the OPEFB, pulp and bleached pulp was shown in Figure 3. Native OPEFB pulp was dominated by fiber with $0.5-1.0 \mathrm{~mm}$ in length. This native OPEFB fiber length is similar to the reference (Khalil et al.,2008). After pulping process, percentage of the $0.5-1.0 \mathrm{~mm}$ fiber length was reduced and percentage of the $0.2-0.5 \mathrm{~mm}$ fiber length was increased. Fine fiber $(0.2-0.5 \mathrm{~mm})$ dominated after pulp bleaching using sodium hypochlorite. It can be seen that these pulping and bleaching process separated the fiber bundles into smaller and shorter fiber size. This phenomenon is also reported in the reference for kenaf fiber (Jonoobi et al., 2009). Treatment of OPEFB could reduce size and dimension of the OPEFB fiber (Norul Izani et al., 2013).

\section{Changes of Functional Groups}

Changes the functional group of the OPEFB bleached pulpafter oxidizing were studied by FTIR analysis. Peak assignment of the FTIR spectra

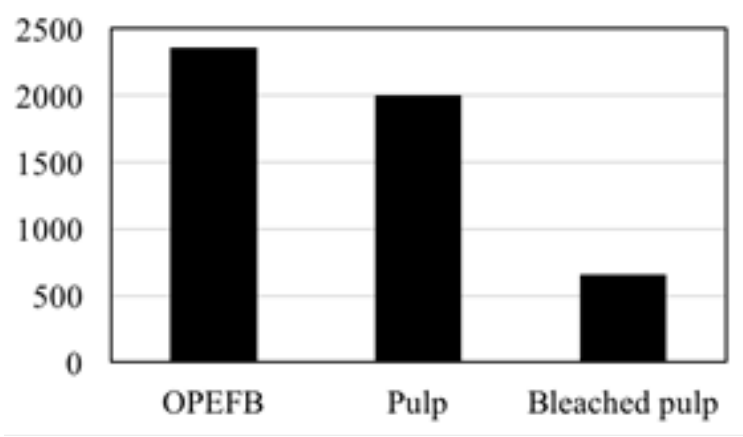

Figure 2. Degree of Polymerization of Oil Palm Empty Fruit Bunch (OPEFB), Pulp, and Bleached Pulp from OPEFB 


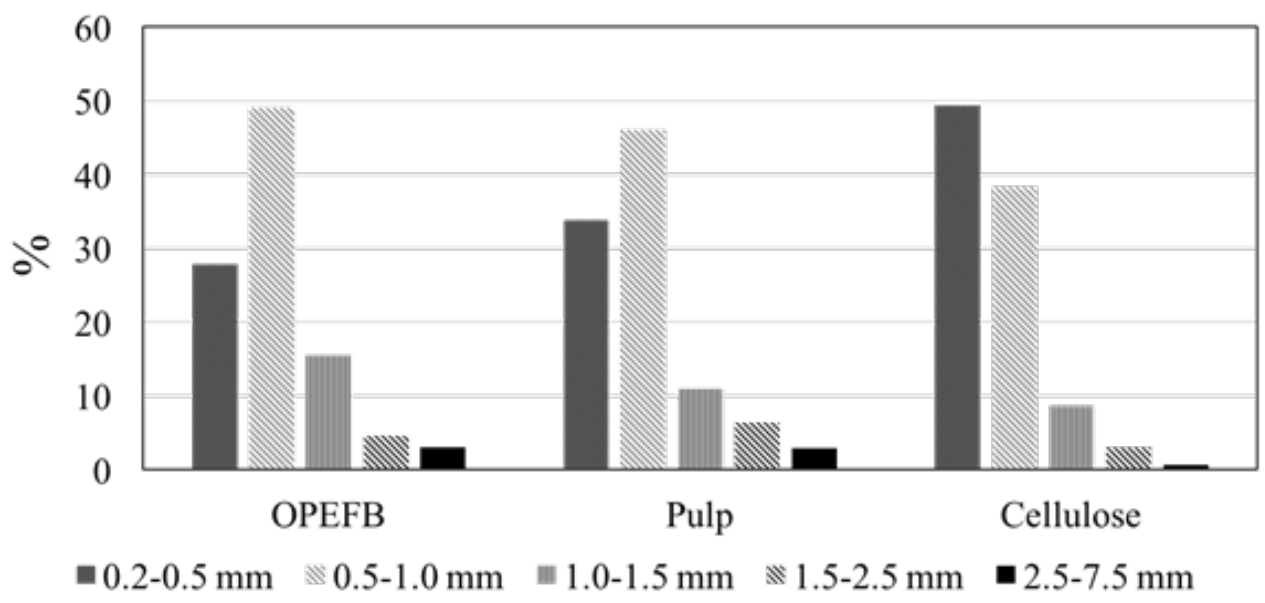

Figure 3. Fiber Length Distribution of Oil Palm Empty Fruit Bunch (OPEFB), Pulp, and Cellulose from OPEFB

was reported in Isroi et al., (2014). Hydrogen peroxide is also known as mild oxidizing agent. Hydrogen peroxide can randomly oxidize the cellulose in various sites. Since hydrogen peroxide behaves as a non-selective oxidation agent, the course of oxidation could be altered and different oxidation products could be obtained (Kramar et al., 2014). In this study, we found that two peaks of the FTIR spectra were affected by hydrogen peroxide treatment, i.e.: 1722 and $1629 \mathrm{~cm}^{-1}$ (Figure 4). These peaks are assigned as nonconjugated carboxyl bond and carbonyl bond, respectively (Łojewska et al., 2005). In Figure 4 shown that peak at 1722 and $1639 \mathrm{~cm}^{-1}$ were increased by increasing hydrogen hydroxide concentration from 3\% to $9 \%$. In control (pulp without sodium hydroxide treatment) $1722 \mathrm{~cm}^{-1}$

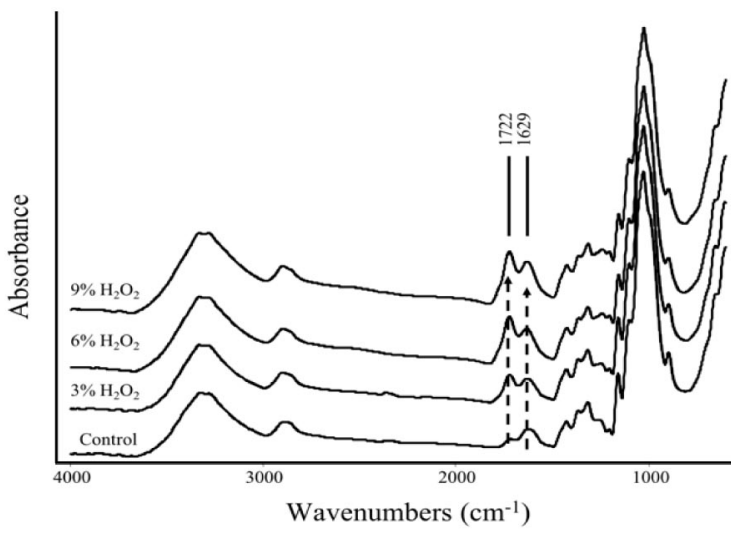

Figure 4. FTIR Absorbance Spectra of Oxidized Cellulose with Different $\mathrm{H}_{2} \mathrm{O}_{2}$ Concentration peak was low. This peak gradually increases with increasing the sodium hydroxide concentration. Increasing of the $1722 \mathrm{~cm}^{-1}$ peak was higher than $1629 \mathrm{~cm}^{-1}$ peak. There are no significant changes in the peaks $2900-3000 \mathrm{~cm}^{-1}$ region. This peaks are assigned to hydrogen bonded $(\mathrm{O}-\mathrm{H})$ stretching absorption (Schwanninger et al., 2004).

The $\mathrm{C}$ atoms in glycopyranose anomer inside the cellulose chain which are the most susceptible to oxidation occupy the 2,3 , and 6 position (Łojewska et al., 2005). Oxidation by hydrogen peroxide of the cellulose could be occurring in these $\mathrm{C}$ atoms position. $\mathrm{C}=\mathrm{O}$ stretch at wave number $1722 \mathrm{~cm}^{-1}$ could be carboxyl or aldehyde absorptions (Stenstad et al., 2008; Łojewska et al., 2005). This peak in control (un-oxidized cellulose) could be from residual hemicelluloses (Faix et al., 1991), since bleached pulp of OPEFB still have about $27 \%$ of hemicelluloses. The carboxyl vibration around $1722 \mathrm{~cm}^{-1}$ representing the final oxidation stage of carbon atoms in glycopyranose rings, increase with the increasing of the hydrogen peroxidase concentration (Łojewska et al., 2005). Oxidation of cellulose with sodium periodate and sodium chlorite introduces carboxyl groups mainly in position 2 and 3 (Luiz Barbosa). Increasing of the carboxyl group of the bleached pulp after hydrogen peroxidase oxidation which is confirmed by titration analysis is presented in Figure 5.

There are several methods to predict the cellulose crystallinity. Crystalinity of the cellulose could be predicted from FTIR peak analysis (Åkerholmetal., 2004; Park etal., 2010). In our experience, LOI (lateral order index) 


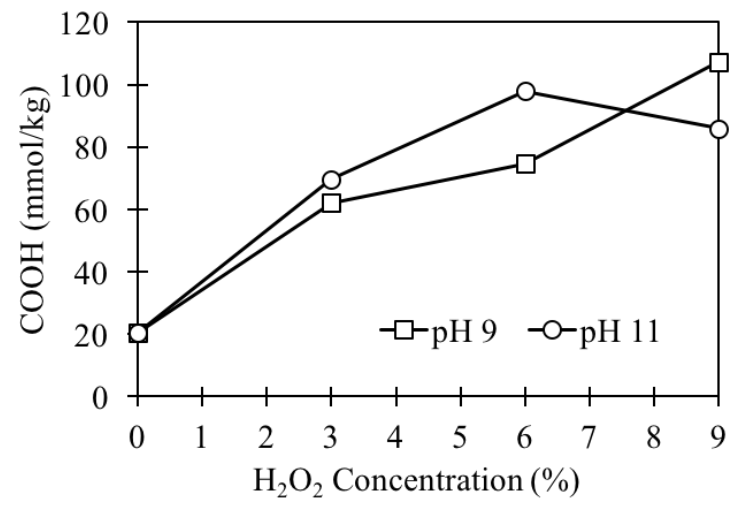

Figure 5. Carboxyl Content of Oxidized Cellulose

is better method for the OPEFB. LOI is ratio between absorbance at wave number 1418 and $895 \mathrm{~cm}^{-1}$ (Hurtubise \& Krässig, 1960; Spiridon et al., 2011). A LOI value of the oxidized cellulose is presented in Figure 6. Crystallinity index of the cellulose was decreased by increasing the hydrogen peroxide concentration. LOI value decreased from 0.553 at control $\left(0 \% \mathrm{H}_{2} \mathrm{O}_{2}\right)$ to 0.507 at $9 \% \mathrm{H}_{2} \mathrm{O}_{2}$. Oxidation of the cellulose seemed to disturb and destroy hydrogen bond between cellulose polymers in the crystalline region of the cellulose micro fibril. LOI value of the oxidized cellulose was lower than the OPEFB reported in Abdul, J. Jahim, et al., (2016).

\section{Cellulose Morphology}

Visual characteristic of the cellulose fiber isolated from OPEFB analyzed using light microscope is shown in Figure 7. Cellulose macro fiber of the bleached OPEFB pulp was apparently

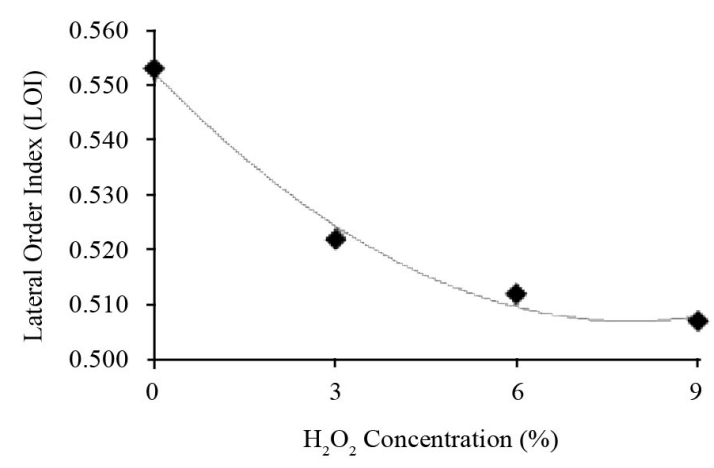

Figure 6. Lateral Order Index (LOI) of The EFB Cellulose Oxidized in Different $\mathrm{H}_{2} \mathrm{O}_{2}$ Concentration: $0 \%$ (Control), 3\%, 6\% and 9\%

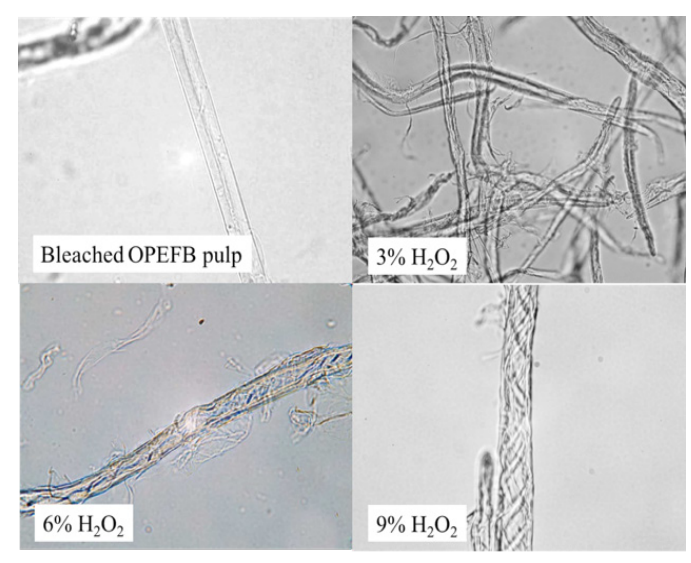

Figure 7. Morphology of The Cellulose Strand Under Light Microscope (400x Magnifications)

smooth and bright under the microscope. Oxidation of the cellulose macro fiber resulted hairy fiber. Microfiber of the cellulose is coming out from the macro fiber look like hairy fiber. Increasing the hydrogen peroxide concentration would increase the microfiber. Hemicelluloses that cover and bend the microfiber cellulose could be oxidized by hydrogen peroxide. Degradation of the hemicelluloses would open the cover of cellulose macro fiber and released the cellulose microfiber. Cellulose polymers also bend by hydrogen bond between cellulose strands. Oxidizing the $\mathrm{C}$ atom into carbonyl could break the hydrogen bond between cellulose as represent in the decreasing of the cellulose crystallinity. Moreover, oxidized cellulose fiber was thinner than the un-oxidized cellulose.

SEM micrograph study of the OPEFB fiber revealed that the macro fiber was composed of smaller microfiber (Norul Izani et al., 2013). Oxidation of the OPEFB cellulose in alkaline condition in this study apparently partially separated the micro fibril cellulose from the fiber bundle. Some fiber linkages were broken up after the treatment. This result confirmed other studies (Zuluaga et al., 2009; Sreekala et al., 1997). OPEFB micro fibril arranged in spiral in the fibril as is shown in Figure 6 at $9 \% \mathrm{H}_{2} \mathrm{O}_{2}$. This evidence supported proposed model of the cellulose in vascular bundle of the OPEFB (Khalil et al., 2012).

\section{Conclusions}

Cellulose was successfully isolated from OPEFB by sodium hydroxide method following 
by sodium hypochlorite treatment. Treatment of the OPEFB by $10 \%$ sodium hydroxide at 2 bars for 6 hours was the best condition to reduce lignin content. Cellulose, hemicelluloses and lignin content of the pulp changed from $60.76 \%$ to $73.87 \%, 25.86 \%$ to $30.95 \%$, and $22.58 \%$ to $16.60 \%$, respectively. Bleaching of the pulp using sodium hypochlorite (5.25\% in water) increase cellulose content to $90.86 \%$ and totally reduced lignin content to $0 \%$. Carbonyl content of the bleached pulp increased by increasing the hydrogen peroxide concentration. Carboxyl content at $9 \%$ hydrogen peroxide was $107.26 \mathrm{mmol} / \mathrm{kg}$ (pH 9) and $85.86 \mathrm{mmol} / \mathrm{kg}(\mathrm{pH} \mathrm{11).} \mathrm{Oxidation}$ of the bleached pulp was also affected the macro fibril resulted hairy microfiber coming out from the cellulose macro fiber. The oxidized cellulose could has better compatibility with others polymers to make a composite materials.

\section{Acknowledgments}

The authors thank the Ministry of Research, Technology and Higher Education who funded this research. The authors also thank Siti Ropikoh, Anggun Rahman, Dewi, and Zaenab for their contribution in laboratory work.

\section{References}

Abdul, P.M., Jahim, J.M., et al., 2016. Effects of changes in chemical and structural characteristic of ammonia fibre expansion (AFEX) pretreated oil palm empty fruit bunch fibre on enzymatic saccharification and fermentability for biohydrogen. Bioresource Technology, 211, pp.200-208. Available at: http:// www.sciencedirect.com/science/article/ pii/S0960852416302814.

Abdul, P.M., Jahim, J., et al., 2016. Effects of changes in chemical and structural characteristic of ammonia fibre expansion (AFEX) pretreated oil palm empty fruit bunch fibre on enzymatic saccharification and fermentability for biohydrogen. Bioresource Technology, 211, pp.200-208. Available at: http://dx.doi.org/10.1016/j. biortech.2016.02.135.

Åkerholm, M., Hinterstoisser, B. \& Salmén, L., 2004. Characterization of the crystalline structure of cellulose using static and dynamic FT-IR spectroscopy. Carbohydrate research, 339(3), pp.569578.
Alavudeen, A. et al., 2015. Mechanical properties of banana/kenaf fiber-reinforced hybrid polyester composites: Effect of woven fabric and random orientation. Materials \& Design (1980-2015), 66, pp.246-257.

De Assis Castro, R.C. et al., 2017. Alkaline deacetylation as a strategy to improve sugars recovery and ethanol production from rice straw hemicellulose and cellulose. Industrial Crops and Products, 106, pp.6573.

Bari, N. et al., 2010. Statistical optimization of process parameters for the production of citric acid from oil palm empty fruit bunches. African Journal of Biotechnology, 9(4), pp.554-563. Available at: http://www. scopus.com/inward/record.url?eid=2-s2.076649110596\&partnerID $=40 \& \mathrm{md} 5=1 \mathrm{f} 8 \mathrm{df3}$ 96c046af1d021e8c3cdd803663.

Brooks, R. \& Moore, S., 2000. Alkaline hydrogen peroxide bleaching of cellulose. Cellulose, 7(3), pp.263-286. Available at: http:// dx.doi.org/10.1023/A\%3A1009273701191.

Chadijah, S., Rustiah, W.O. \& Munir, M.I.D., 2018. Determination of the optimum concentration cellulose baggase in making film bioplastic. In Journal of Physics: Conference Series. p. 12026.

Chesson, A., 1981. Effects of sodium hydroxide on cereal straws in relation to the enhanced degradation of structural polysaccharides by rumen microorganisms. Journal of the Science of Food and Agriculture, 32(8), pp.745-758.

Coseri, S. et al., 2013. Oxidized cellulose Survey of the most recent achievements. Carbohydrate Polymers, 93(1), pp.207-215. Available at: http://dx.doi.org/10.1016/j. carbpol.2012.03.086.

Dirjenbun, 2015. Statistik Perkebunan Indonesia: Kelapa sawit 2014-2015, Available at: http://ditjenbun.pertanian. go.id/tinymcpuk/gambar/file/statistik/2016/ SAWIT 2014-2016.pdf.

Fahma, F. et al., 2010. Isolation, preparation, and characterization of nanofibers from oil palm empty-fruit-bunch (OPEFB). Cellulose, 17(5), pp.977-985. Available at: http://www. scopus.com/inward/record.url?eid=2-s2.077955368294\&partnerID $=40 \& \mathrm{md} 5=1938 \mathrm{a} 6$ d741151645c0629f4587cc16db.

Faix, O. et al., 1991. Monitoring of chemical changes in white-rot degraded beech wood by pyrolysis-Gas chromatography and Fourier-transform infrared spectroscopy. Journal of Analytical and Applied Pyrolysis, 21(1), pp.147-162. 
Fras, L. \& Stana-Kleinschek, K., 2002. Quantitative determination of carboxyl groups in cellulose by complexometric titration. Lenzinger ..., pp.80-88. Available at: http://www.lenzing. com/fileadmin/template/pdf/konzern/ lenzinger_berichte/ausgabe_81_2002/ LB_2002_Fras_16_ev.pdf.

Hamzah, F., Idris, A. \& Shuan, T.K., 2011. Preliminary study on enzymatic hydrolysis of treated oil palm (Elaeis) empty fruit bunches fibre (EFB) by using combination of cellulase and \$ \$ 1-4 glucosidase. biomass and bioenergy, 35(3), pp.1055-1059. Available at: http://dx.doi.org/10.1016/j. biombioe.2010.11.020.

Haque, M.M. et al., 2009. Physico-mechanical properties of chemically treated palm and coir fiber reinforced polypropylene composites. Bioresource Technology, 100(20), pp.4903-4906.

Hubbell, C.A. \& Ragauskas, A.J., 2010. Effect of acid-chlorite delignification on cellulose degree of polymerization. Bioresource Technology, 101(19), pp.7410-7415. Available at: http://dx.doi.org/10.1016/j. biortech.2010.04.029.

Hurtubise, F.G. \& Krässig, H., 1960. Classification of fine structural characteristics in cellulose by infared spectroscopy. Use of potassium bromide pellet technique. Analytical Chemistry, 32(2), pp.177-181.

Isroi, 2015. Biological Pretreatment of Oil Palm Empty Fruit Bunches. In 2nd International Symposium on Integrated Biorefinary (ISIBio). Bogor, pp. 1-12.

Isroi, Mofoluwake, I. \& Taherzadeh, M.J., 2014. Effect of fungal and phosphoric acid pretreatment on ethanol production from oil palm empty fruit bunches (OPEFB). Bioresource Technology.

Jonoobi, M. et al., 2009. Chemical composition, crystallinity, and thermal degradation of bleached and unbleached kenaf bast (Hibiscus cannabinus) pulp and nanofibers. BioResources, 4(2), pp.626-639.

Khalid, M. et al., 2008. Comparative study of polypropylene composites reinforced with oil palm empty fruit bunch fiber and oil palm derived cellulose. Materials \& Design, 29(1), pp.173-178.

Khalil, H.P.S.A. et al., 2008. Chemical composition, morphological characteristics, and cell wall structure of Malaysian oil palm fibers. Polymer - Plastics Technology and Engineering, 47(3), pp.273-280.

Khalil, H.P.S.A., Bhat, A.H. \& Yusra, A.F.I., 2012. Green composites from sustainable cellulose nanofibrils: A review. Carbohydrate Polymers, 87(2), pp.963-979.
Kitaoka, T., Isogai, A. \& Onabe, F., 1999. Chemical modification of pulp fibers by TEMPOmediated oxidation. Nordic Pulp and Paper Research Journal, 14(4), pp.279-284.

Kramar, A.N.A. et al., 2014. Cellulose chemistry and technology influence of structural changes induced by oxidation and addition of silver ions on electrical properties of cotton yarn. , 48, pp.189-197.

Lani, N.S. et al., 2014. Isolation, characterization, and application of nanocellulose from oil palm empty fruit bunch fiber as nanocomposites. Journal of Nanomaterials, 2014, p.13.

Law, K.-N., Daud, W.R.W. \& Ghazali, A., 2007. Morphological and chemical nature of fiber strands of oil palm empty-fruit-bunch (OPEFB). BioResources, 2(3), pp.351-362.

Łojewska, J. et al., 2005. Cellulose oxidative and hydrolytic degradation: In situ FTIR approach. Polymer Degradation and Stability, 88(3), pp.512-520.

Ma, P. et al., 2010. Influence of oxidation and cationization on the properties of thermomechanical pulp fibers. Tappi Journal, 9(10), pp.36-43.

Mohd, N.H. et al., 2017. Properties of Aminosilane Modified Nanocrytalline Cellulose (NCC) from Oil Palm Empty Fruit Bunch (OPEFB) Fibers. Materials Science Forum, 888(March), pp.284-289. Available at: http://www.scientific.net/MSF.888.284.

Mosier, N. et al., 2005. Features of promising technologies for pretreatment of lignocellulosic biomass. Bioresource technology, 96(6), pp.673-686.

Norul Izani, M.A. et al., 2013. Effects of fiber treatment on morphology, tensile and thermogravimetric analysis of oil palm empty fruit bunches fibers. Composites Part $B$ : Engineering, 45(1), pp.1251-1257.

Park, S. et al., 2010. Cellulose crystallinity index: measurement techniques and their impact on interpreting cellulase performance. Biotechnology for Biofuels, 3(1), p.10. Available at: http:// www.biotechnologyforbiofuels.com/ content $/ 3 / 1 / 10$.

Piarpuzán, D., Quintero, J.A. \& Cardona, C.A., 2011. Empty fruit bunches from oil palm as a potential raw material for fuel ethanol production. Biomass and Bioenergy, 35(3), pp.1130-1137.

Pujiasih, S. et al., 2018. Silylation and characterization of microcrystalline cellulose isolated from indonesian native oil palm empty fruit bunch. Carbohydrate Polymers, 184, pp.74-81. Available at: http://dx.doi. org/10.1016/j.carbpol.2017.12.060. 
Rahman, S.H.A. et al., 2007. Optimization studies on acid hydrolysis of oil palm empty fruit bunch fiber for production of xylose. Bioresource Technology, 98(3), pp.554-559. Available at: http://www.ncbi.nlm.nih.gov/ pubmed/16647852.

Schwanninger, M. et al., 2004. Effects of shorttime vibratory ball milling on the shape of FT-IR spectra of wood and cellulose. Vibrational Spectroscopy, 36(1), pp.23-40.

Shen, L., Worrell, E. \& Patel, M., 2010. Present and future development in plastics from biomass. Biofuels, Bioproducts and Biorefining, 4(1), pp.25-40.

Shinoj, S. et al., 2011. Oil palm fiber (OPF) and its composites: A review. Industrial Crops and Products, 33(1), pp.7-22. Available at: http:// dx.doi.org/10.1016/j.indcrop.2010.09.009.

Sklavounos, E. et al., 2013. Oil palm empty fruit bunch to biofuels and chemicals via SO2-ethanol-water fractionation and ABE fermentation. Bioresour Technol, 147, pp.102-109. Available at: http://www.ncbi. nlm.nih.gov/pubmed/23994956.

Spiridon, I., Teaca, C.A. \& Bod $\wedge^{\wedge}$ irlluau, R., 2011. Structural changes evidenced by FTIR spectroscopy in cellulose materials after pretreatment with ionic liquid and enzymatic hydrolysis. BioResources, 6(1), pp.400-413.

Sreekala, M.S., Kumaran, M.G. \& Thomas, S., 1997. Oil palm fibers: Morphology, chemical composition, surface modification, and mechanical properties. Journal of Applied Polymer Science, 66(5), pp.821-835. Available at: $\quad$ http://dx.doi.org/10.1002/(SICI)10974628(19971031)66:5\%3C821::AIDAPP2\%3E3.0.CO;2-X.
Stenstad, P. et al., 2008. Chemical surface modifications of microfibrillated cellulose. Cellulose, 15(1), pp.35-45.

Suhas, Carrott, P.J.M. \& Ribeiro Carrott, M.M.L., 2007. Lignin - from natural adsorbent to activated carbon: A review. Bioresource Technology, 98(12), pp.2301-2312.

Swatloski, R.P. et al., 2002. Dissolution of cellose with ionic liquids. Journal of the American Chemical Society, 124(18), pp.4974-4975.

Taylor, M.C. et al., 1940. Sodium Hypochlorite Properties and Reactions. Ind. Eng. Chem., 32(7), pp.899-903.

Varshney, V.K. \& Naithani, S., 2011. Cellulose Fibers: Bio- and Nano-Polymer Composites. , pp.43-61. Available at: http://link.springer. com/10.1007/978-3-642-17370-7.

Zhang, D. et al., 2012. Optimization of dilute acid-catalyzed hydrolysis of oil palm empty fruit bunch for high yield production of xylose. Chemical Engineering Journal, 181, pp.636-642.

Zianor Azrina, Z.A. et al., 2017. Spherical nanocrystalline cellulose (NCC) from oil palm empty fruit bunch pulp via ultrasound assisted hydrolysis. Carbohydrate Polymers, 162(17), pp.115-120. Available at: http:// dx.doi.org/10.1016/j.carbpol.2017.01.035.

Zuluaga, R. et al., 2009. Cellulose microfibrils from banana rachis: Effect of alkaline treatments on structural and morphological features. Carbohydrate Polymers, 76(1), pp.51-59. 
- This page is intentionally left blank - 